\title{
Involvement of Apatani women of Arunachal Pradesh in farm and home activities
}

\author{
OYANG DANI*, MINERVA SAIKIA BARUAH AND MANJU DUTTA DAS \\ Department of Extension and Communication Management, College of Home Science, \\ Assam Agricultural University, JORHAT (ASSAM) INDIA
}

\begin{abstract}
The present investigation was undertaken to study the involvement of Apatani women of Arunachal Pradesh in farm and home activities with the objective to study the selected socio-personal characteristics of Apatani women of Arunachal Pradesh and to identify the extent of involvement of Apatani women in selected farm and home activities. The study was conducted in Lower Subansiri district of Arunachal Pradesh. Four villages were selected for the present study. Data were collected with the help of interview schedule. Statistical technique viz., frequency, percentage, mean and standard deviation and coefficient correlation were used for analyzing the data. The study revealed that majority of the respondents were within the age group of 30-40, belonged to Hindu religion were mostly illiterate, married, having nuclear family and member of one organization. Observations revealed that all the respondents independently participated in sowing of seed, nursery raising, leveling of field, weeding, gap filing and application of organic manure. The findings revealed that correlation between extent of participation in farm activities and land holding was negative and significant. While relationship between extent of participation in home activities with family size was positive and significantt. The mass media exposure and occupation of the family had positive and significant relationship with extent of participation in decision making pattern in home activities. The correlation between extent of participation in farm activities and land holding was negative and significant while relationship between extent of participation in home activities with family size was positive and significant.
\end{abstract}

KEY WoRDS : Involvement, Apatani women, Farm, Home activities

View Point Article : Dani, Oyang, Baruah, Minerva Saikia and Das, Manju Dutta (2014). Involvement of Apatani women of Arunachal Pradesh in farm and home activities. Internat. J. Home. Sci. Extn. \& Comm. Mgmt., 1 (2): 51-56.

Article History : Received : 08.01.2014; Revised : 01.05.2014; Accepted : 15.05.2014

\footnotetext{
* Author for correspondence
} 